\title{
Integrating historical topographic maps and SRTM data to derive the bathymetry of a tropical reservoir
}

\author{
Enner Alcântara ${ }^{\mathrm{a}^{*}}$, Evlyn Novo $^{\mathrm{a}}$, José Stech ${ }^{\mathrm{a}}$, Arcilan Assireu ${ }^{\mathrm{a}}$, Renata Nascimento ${ }^{\mathrm{a}}$, \\ João Lorenzzetti ${ }^{\mathrm{a}}$, Arley Souza ${ }^{\mathrm{a}, \mathrm{b}}$ \\ ${ }^{a}$ Divisão de Sensoriamento Remoto, Instituto Nacional de Pesquisas Espaciais - INPE \\ ${ }^{b}$ CETEC-ETEP Faculdades, Brasil \\ \{evlyn,stech,,arcilan,renata,loren\}@dsr.inpe.br; arley@dpi.inpe.br \\ *Corresponding author: enner@dsr.inpe.br
}

\begin{abstract}
This paper proposes a cheap and fast method for estimating the bathymetry of hydroelectric reservoirs. Brazil has more than 30 large hydroelectric reservoirs with volume exceeding one billion cubic meters. The hydroelectric sector is responsible for $97 \%$ of energy generation being the largest hydroelectric park in the world. These dams, however, cause a series of environmental, social and economic impacts, which need to be monitored. Among the variables affecting the environmental impact posed by reservoirs, depth has a key role because it acts on the aquatic system hydrodynamics. Reservoir depth distribution, the bathymetry, is also a fundamental factor controlling physical-chemical and biological properties of the system. In Brazil, the acquisition of bathymetric information for the large reservoirs, however, is not a simple task, because: 1) most of the topographic maps available in the area covered by the lake have very small scale (1:100 000 and smaller); 2) larger charts are property of the hydropower companies and are classified; 3 ) the size of the reservoirs prevent the use of bathymetric surveys due. The challenge therefore is how to combine the use of low precision topographic charts from the period previous to reservoir filling, SRTM data to obtain a bathymetric map which could be used for planning echo-bathymetric missions so as reducing both cost and time of data acquisition and processing.
\end{abstract}

Keywords: hydroelectric sector, echo-sounder, geoprocessing, water resources. 


\section{Introduction}

In accordance to World Commission Dams (WCD, 2000) up to 60\% of 227 largest rivers of the world was hard or moderate fragmented by dams, deviated or canalized, causing effects on inland water ecosystems and surroundings.

The environmental impacts caused by dammed rivers (Tundisi, 1994) are associated with their size and volume, time of residence and geographical localization, being the main ones: flooding of agricultural areas, alteration of fish migration, loss of aquatic flora and fauna, change of hydrological regime, sediment yielding, dissemination of disease vectors, loss of historical and cultural sites, social effects and on local economical activities. One of key parameter to characterize and understanding a lot of processes in aquatic systems is the bathymetry.

In many studies the bathymetry is a necessary input parameter, as sediment deposition through the time (Rowan et al. 1995, Gaytán et al., 2008), water quality modeling (Tufford \& McKellar, 1999), circulation and thermal structure modeling (Beletsky \& Schwab, 2001), modeling of macrophyte distribution (Lehmann, 1998), fish ecology (Jepsen et al. 1999), management (Awulachew, 2006), embankments dams (Charles, 2009), and others.

Moreover, often the bathymetry inventory of reservoirs is realized by echo-sounders that are based on time pass between sending pulses and the reception of these pulses after their reflection by bottom (Barbosa et al. 2006). The conventional measuring bottom depth is generally a expensive procedure and consuming time. Some authors developed methods based on remote sensing to map the bottom depth (Krug \& Noernberg, 2007, Lafon et al. 2002, Brando et al. 2009) with relatively success in shallow water bodies and low turbidity. However, using this type of method an extensive sampling delineation is required to validate the developed models.

Thus, the objective of this work is to develop a cheap method to map the bottom depth of a tropical hydroelectric reservoir.

Study Area and background - The Itumbiara hydroelectric reservoir $\left(18^{\circ} 25^{\prime} \mathrm{S}\right.$, $49^{\circ} 06^{\prime} \mathrm{W}$ ) is located on tropical grassland savanna, between Minas Gerais and Goiás States (Brazil's central). The reservoir was formed by damming the Parnaiba River which resulted in the backward flood of its main tributaries, Araguari River and Corumbá. The basin geomorphology resulted in a lake with a dentritic pattern covering an area of approximately $814 \mathrm{Km}^{2}$ and volume of $17.03 \mathrm{~m}^{3}$ (Figure 1). 
(a)

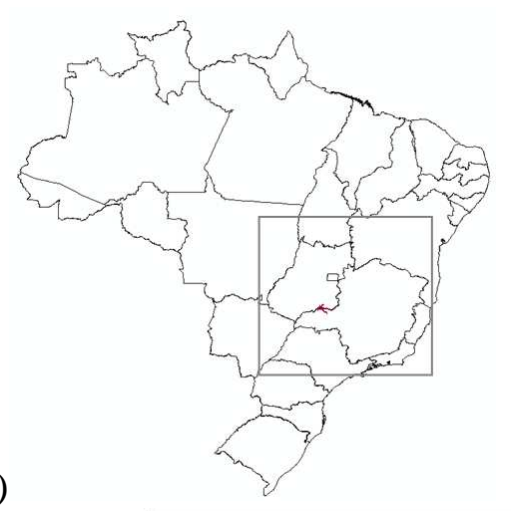

(b)

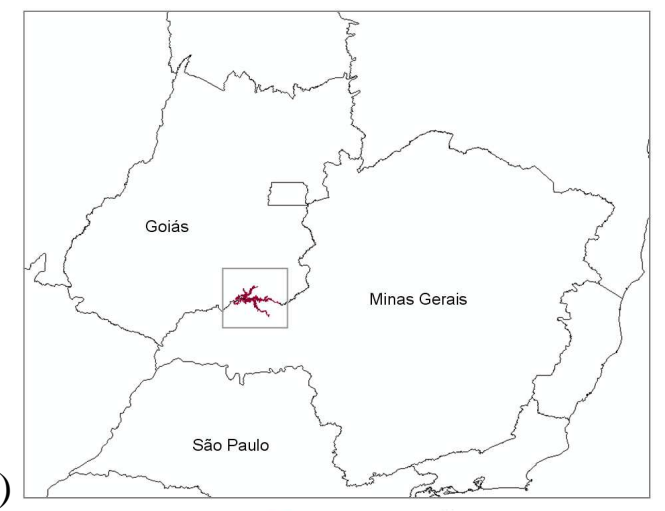

(c)

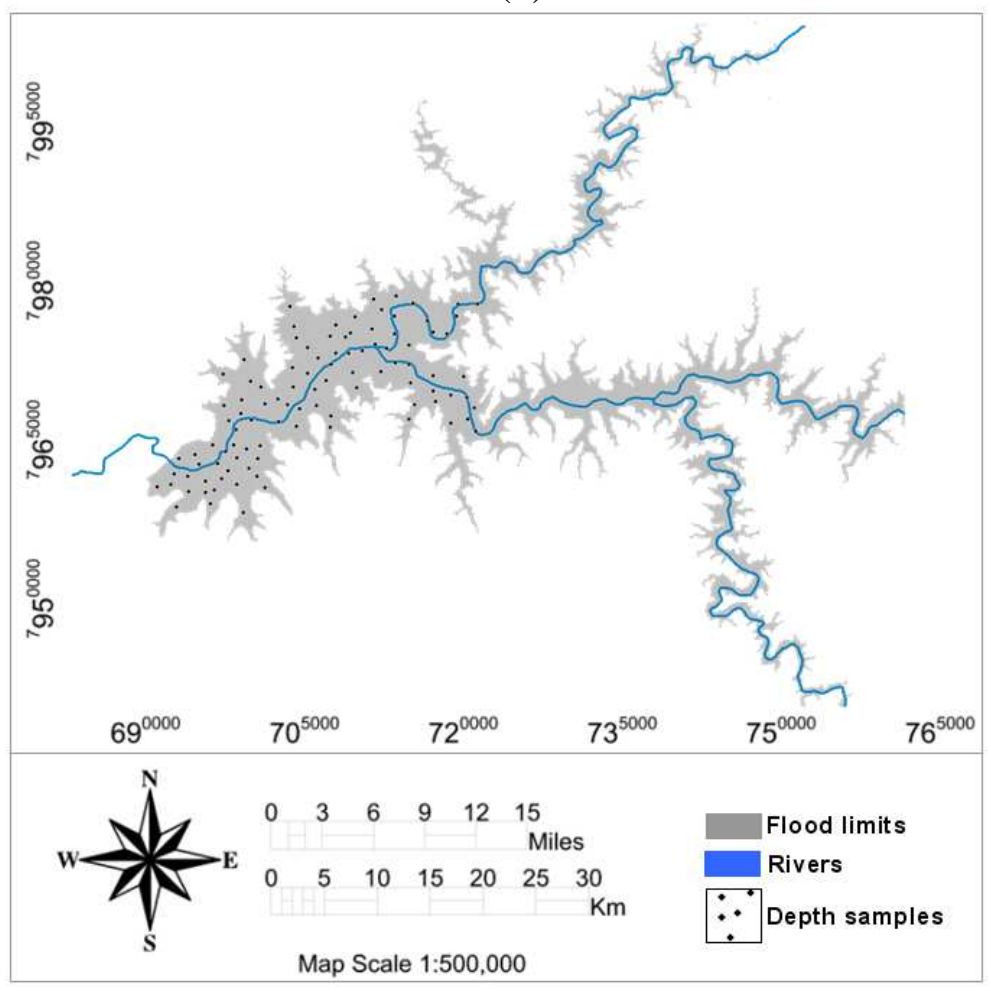

Figure 1: Localization of Itumbiara hydroelectric reservoir on Brazil's central (a), on state context (b) and on regional scale (c).

The reservoir was building in 1979 and stats your operation on 1980 (Mello, 1980). The figure 2 shows the reservoir area before the flooding (Figure 2-a) and after (Figure 2-b). As can be observed in Figure 2 it is easy to imagine the environmental, social and economic impacts caused by the dam. 


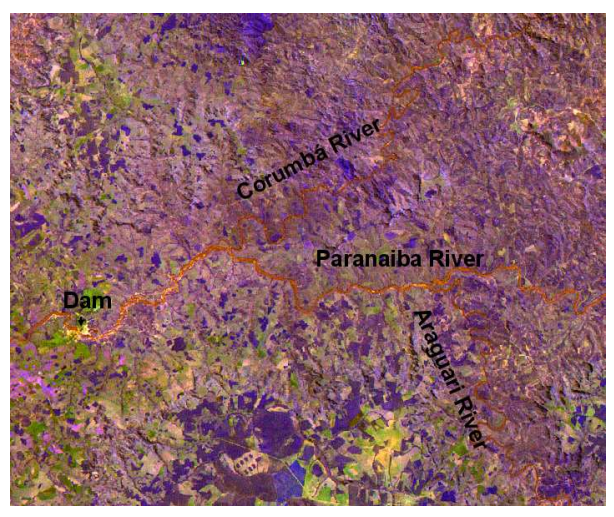

(a)

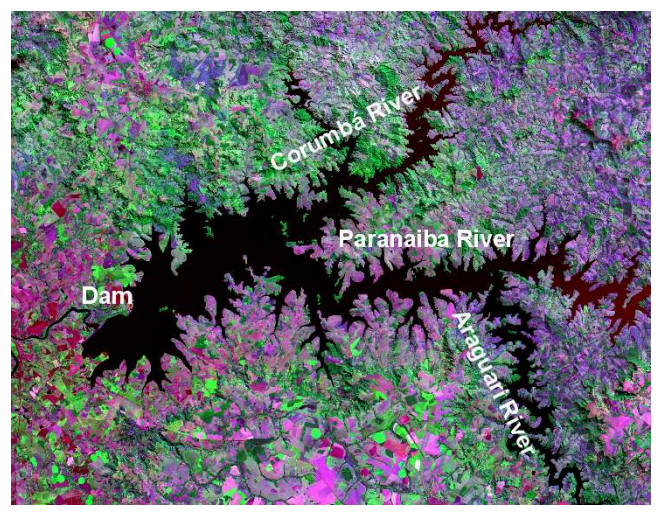

(b)

Figure 2: (a) MSS-Landsat-3 imagery from 11-08-1978 show the area before inundation; and (b) TM-Landsat-5 imagery from 26-05-2007 actual period. The figure also shows the position of dam on reservoir.

The following section provides all methodological bases to reach the objective proposed here.

\section{Methodological approach}

Cartographic Data - a topographic map from 1979 at the scale of 1:250.000 (SE-22-Z-

a) with contour lines spaced every $50 \mathrm{~m}$ was used (DSG, 1979). This map was produced before reservoir construction and allows an overall idea of the topography of the area to be submersed. .

Remote Sensing Data - A SRTM (Shuttle Radar Topography Mission) from 2000, with spatial resolution of $90 \mathrm{~m}$ (Farr et al. 2007) and resized to 30m using the approach proposed by Valeriano et al. (2006) was used to refine the information on the topographic chart. A Landsat-5 TM image from May 262007 was also acquired to represent the maximum water level in the Itumbiara reservoir and to define the land/water limit.

Water Level Data - The water level was record from 1993 to 2008 in each hour measured by 'FUNAS Centrais Elétricas S.A.' (Figure 3). These data was collected near the dam structure $\left(18^{\circ} 24^{\prime} 22,83^{\prime \prime} \mathrm{S}, 49^{\circ} 05^{\prime} 48,25^{\prime \prime} \mathrm{W}\right)$.

Depth Data - A field campaign was carried out using a Lowrance LMS-480 sound from may 11-15 2009 to measure water quality data and depth data in 25 stations in whole reservoir (see Figure 1-c for samples location). 


\section{Method}

Water Level Dynamics and Water Mask - A monthly mean water level from 2003 to 2008 was used to classify the periods of rising, high, falling and low water regime and the rate of variation $\left(\frac{d C}{d t}\right)$, see Figure 3 . These classifications are in accordance to methodology proposed in Barbosa et al. (2006).

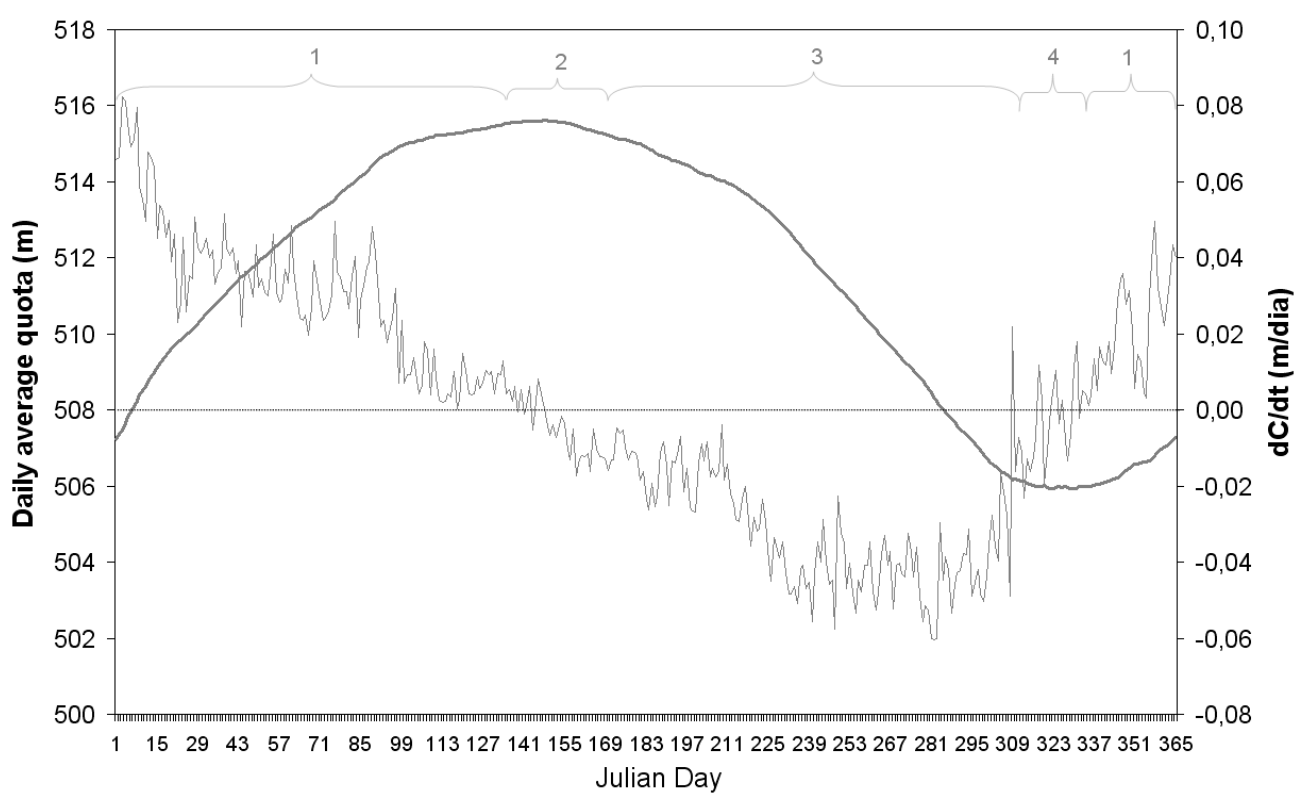

Figure 3: Daily mean variation and rate of water level variation: rising (1), high (2), falling (3) and low water level (4).

According to the water level fluctuation (Figure 3) the best period for carrying out the bathymetry is from April 21 to June 07, because it corresponds to the smallest time change in quota. Based on this the water mask was built using the Landsat-5 TM image acquired May 262007 which was the only date available in the period. The mask was built using the NDWI (Normalized Difference Water Index) algorithm proposed by McFeeters (1996).

Estimating the bottom depth - The topographic map from 1979 was digitized (Figure 4a) using the Computer-Aided Design (CAD) software to generate a digital topographic map. The contour curve interval was $50 \mathrm{~m}$ providing a very poor display of the terrain (Figure 4-a and b). A SRTM image with contour curve intervals of 20m (Figure 4-c and d) shows the lack of information in the flooded area since it was acquired in 2000 . The backscattering from the water surface is almost zero because SRTM sensor operates in bands $\mathrm{C}$ and $\mathrm{X}$ and is only sensitive to differences in water surface roughness. In the 
area surrounding the reservoir, however, SRTM displays a much finer representation of the terrain topography (Figure 4-d) as compared with that displayed by the topographic map (Figure 4-b)

By merging the two data sets, using the SRTM to improve the vertical resolution of the topographic map in the region bordering the reservoir, it was possible to generate a hybrid map with an improved quality. This procedure allowed generating a third contour map (Figure 4-e) and its image (Figure 4-f) with a clear improvement of the vertical resolution and much better display of the terrain even inside the flooded area

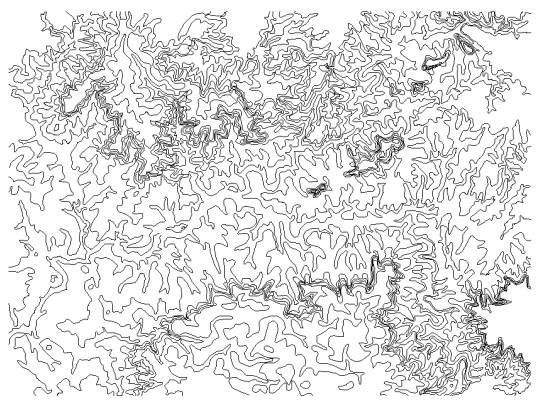

(a)

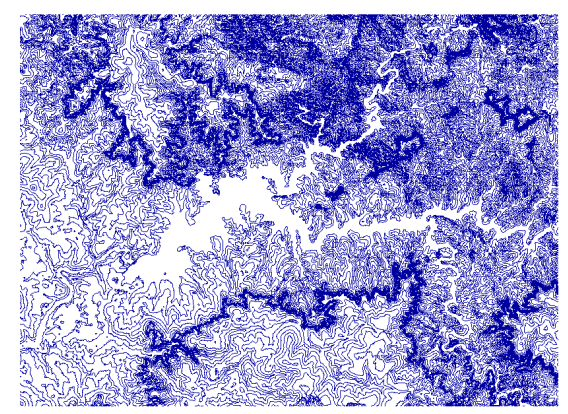

(c)

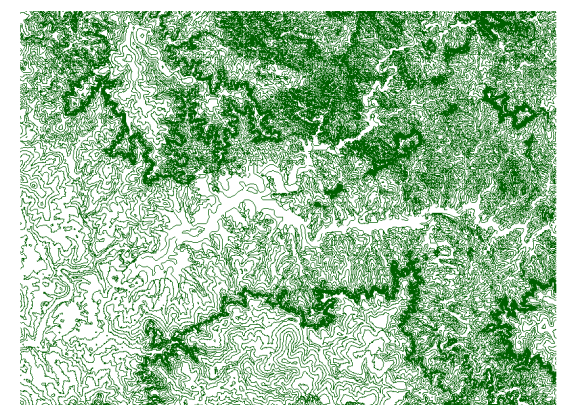

(e)

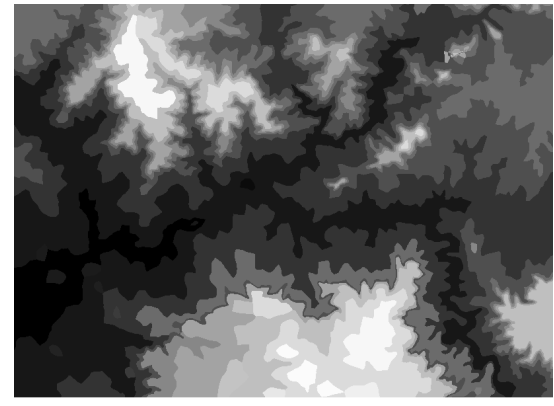

(b)

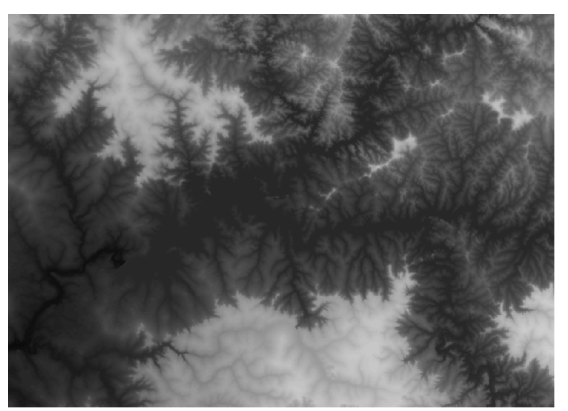

(d)

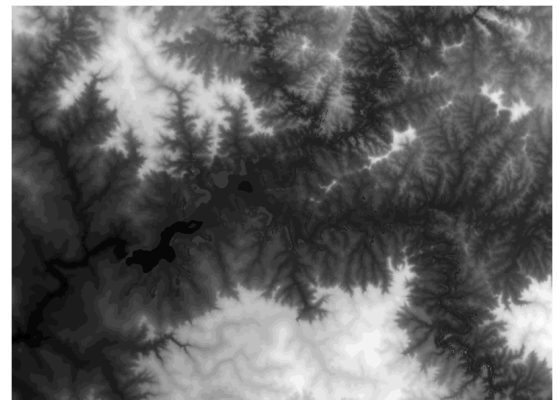

(f)

Figure 4: Methodological approach used to enhance the topography map of flooded area of Itumbiara reservoir. (a) Curve levels of $50 \mathrm{~m}$ derived from topography map of 1979 and the image (b); (c) curve level of 20 m derived from SRTM from 2000 and their image (d); and the enhanced curve levels (e) and their image (f). 
From topography to bathymetry - The hybrid map was then used to transform the enhanced topography map (see Figure 4-f) in bathymetry. This transformation consisted of an operation of pixel subtraction from the known reference water level $\left(h_{w}=515 \mathrm{~m}\right)$ for the highest quote (Figure 5).
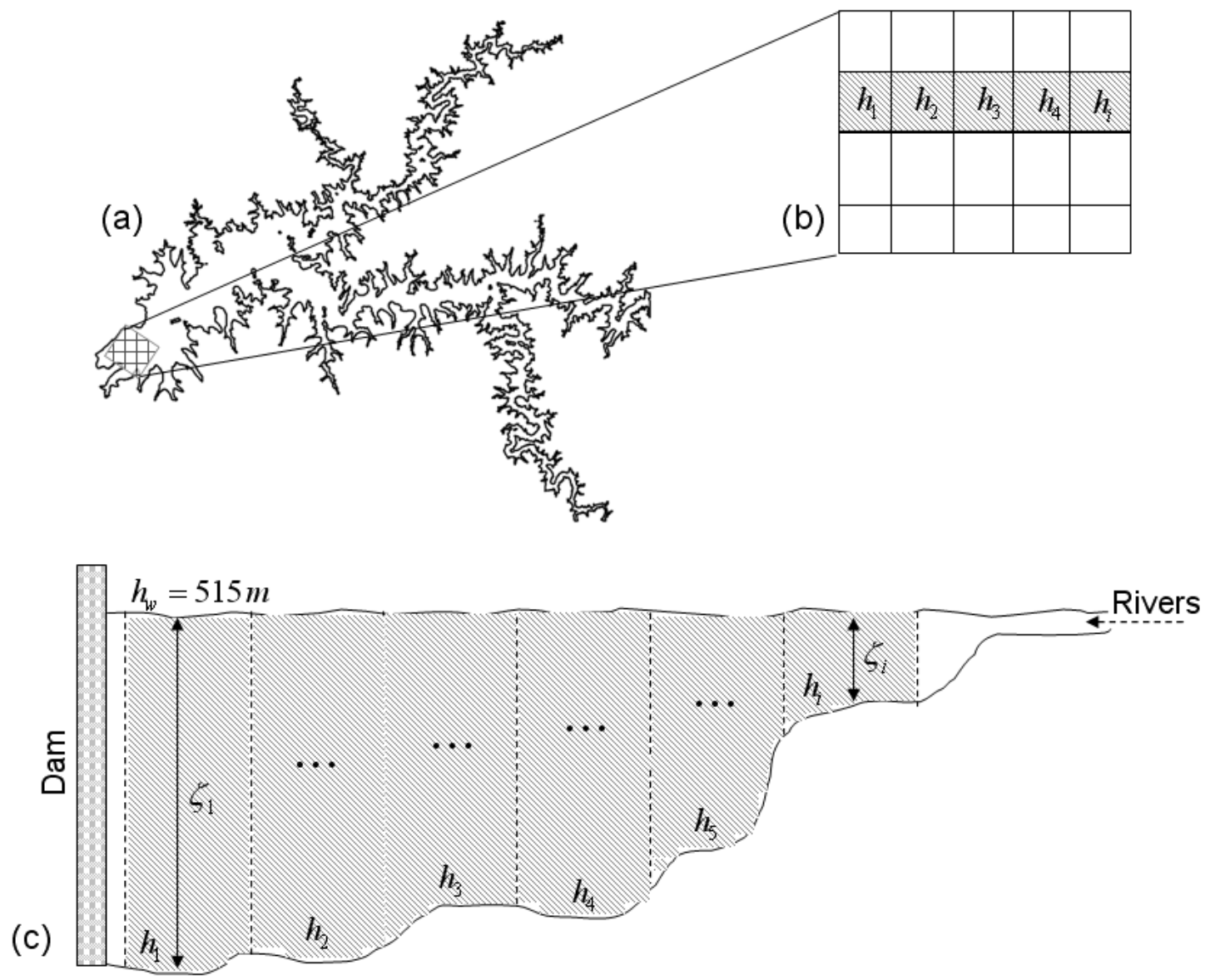

Figure 5: Simplified scheme used to transform the enhanced topography map in bottom depth: (a) water-land limit showing a small test area and (b) the detail of how the topographic level in a small area is organized allowing the transformation of the reference level $h_{w}=515 \mathrm{~m}$ differences to topographic height (h1, h2,,,hn) for each pixel into depth information.

The equation used in this transformation is:

$\zeta_{i}=h_{w}-h_{i}$

Where $\zeta_{i}$ is the bottom depth at the $\mathrm{i}^{\text {th }}$ pixel of the image $(\mathrm{m}), h_{i}$ is the height in the $\mathrm{i}^{\text {th }}$ pixel of the image and $h_{w}$ is a constant equal to the reference level for the highest quota. 
Sensitivity analysis of the method - The sensitivity analysis was carried out using 25 depth measurements (see Figure 1-c for sample location) and confronting with the depth estimated by the method at the same geolocation.

\section{Results}

Figure 6 shows estimated bottom depths for the entire reservoir. Depths near the dam are approximately $70 \mathrm{~m}$ (region 1). This region seems to be the deepest of the reservoir in conjunction with region 2 with $65 \mathrm{~m}$. Both are near the main river (see Figure 1 for location of the rivers before the inundation). The region 3 represents the areas with depth between 25-40 m occurring mainly in the central body of the reservoir.

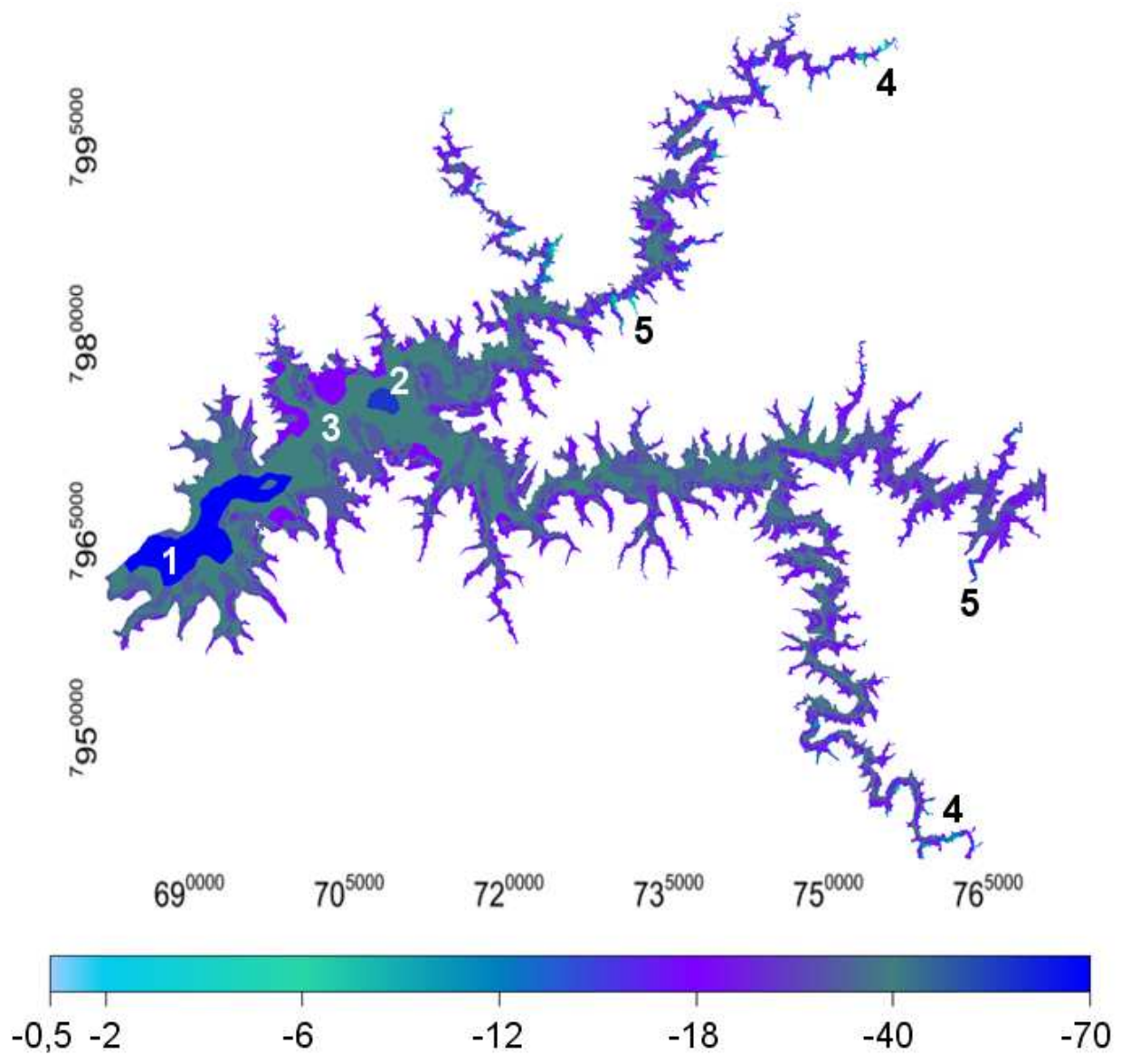

Figure 6: Estimated bathymetry $(\mathrm{m})$ by the proposed method.

According to Figure 6 the shallow areas are in the regions 4 and 5 corresponding to the first order channels running straight into the reservoir. These results agree with the literature (Tundisi et al., 2002), that is, the deepest regions near the dam and shallowest region in the small channels. 
Figure 7a renders a quantitative assessment of the method. The scatterplot of measured and estimated depths display a $\mathrm{R}^{2}=0.98(n=100, \rho=0.00)$. The highest errors were observed depths higher than $70 \mathrm{~m}$. This failure was already expected because the topographic surveys do not include information on river depth. In spite of that, these results are very useful for planning the bathymetric survey in the reservoir, focusing the data collection on the river channel which is the main source of error, and limiting the number of sampling sites in the regions where the hybrid topographic chart renders a good display of reservoir depth distribution.

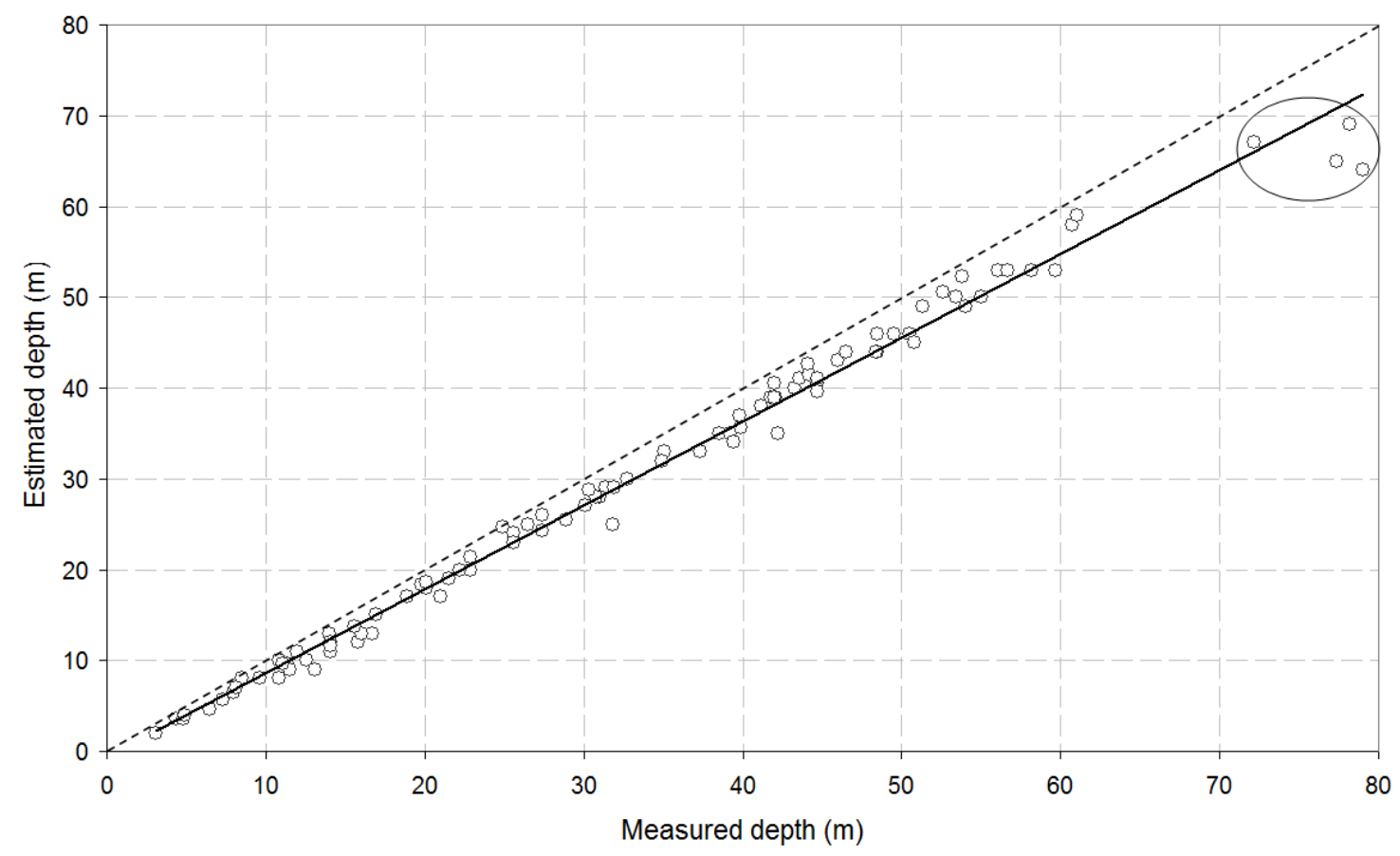

Figure 7: Evaluation of the proposed methodology: (a) measured versus estimated depth (m) and (b) the residuals.

In a country as Brazil where the hydroelectric energy is responsible for $97 \%$ of the total generated energy and considering the valuable information generated by the bathymetric map for reservoir operations the methodology should be applied with relatively success with economy of time, people for surveying and financial resources.

\section{Final remarks}

We present a new method to estimate the bottom depths in hydroelectric reservoirs using cartographic maps and satellite topographic data. Our approach allows the following applications:

- Planning field campaigns;

- Decision making by the engineers; 
- Bathymetry using sonar;

- Water quality sampling;

- Modelling the sedimentation processes in reservoirs over time.

\section{Acknowledgements}

E. Alcântara and colleagues are grateful to Project n. 0258059 PROCAD/CAPES for the $\mathrm{PhD}$ fellowship and the Brazilian funding agency FAPESP under grants 2007/08103-2. We also wish to thanks Carsten Reinhard from School of Biological Sciences, University of Bristol for the English language review.

\section{References}

Awulachew, S.B., 2006: Investigation of physical and bathymetric characteristics of Lakes Abaya and Chamo, Ethipia, and their management implications. Lakes \& Reservoirs: Research and Management. 11: 133-140.

Barbosa, C.C.F., Novo, E.M.L.M., Melack, J.M., Freitas, R.M. \& Filho, W.P., 2006: Metodologia de análise da dinâmica de área e volume inundável: o exemplo da várzea do Lago Grande de Curuaí. Revista Brasileira de Cartografia. 58: 201-210.

Beletsky, D. \& Schwab, D.J., 2001: Modeling circulation and thermal structure in Lake Michigan: annual cycle and interannual variability. Journal of Geophysical Research. 106: 19745-19771.

Brando, V.E., Anstee, J.M., Wettle, M., Dekker, A.G., Phinn, S.R. \& Roelfsema, C. 2009: A physics based retrieval and quality assessment of bathymetry from suboptimal hyperspectral data. Remote Sensing of Enviroment. 113: 755-770.

Charles, J.A. 2009: The engineering behavior of fill materials and its influence on the performance of embankment dams. Dams and Reservoirs. 19: 1, 21-33.

Farr, T. G., et al. 2007: The Shuttle Radar Topography Mission, Reviews of Geophysics, 45: RG2004.

Gaytán, R., Anda, J. \& Nelson, J. 2008: Computation of changes in the run-off regimen of the Lake Santa Ana watershed (Zacatecas, México). Lakes \& Reservoirs: Research and Management. 13: 155-167.

Jepsen, N., Koed, A. \& Okland, F. 1999: The movements of pikeperch in a shallow reservoir. Journal of Fish Biology. 54: 1083-1093.

Kelman, J., Pereira, M.V.F., Neto, T.A.A. \& Sales, P.R.H. 2002: Hidreletricidade. In: Rebouças, A.C.; Braga, B.; Tundisi, J.G. (eds.) Águas Doces no Brasil. São Paulo: escrituras, pp. 371-418. 
Krug, L.A. \& Noernberg, M.A. 2007: O sensoriamento remoto como ferramenta para determinação de batimetria de baixios na Baía das Laranjeiras, Paranaguá-PR. Revista Brasileira de Geofísica. 25: 101-105.

Lafon, V.; Froidefond, J.M.; Lahet, F. \& Castaing, P. 2002: Spot shallow water bathymetry of a moderately turbid tidal inlet based on field measurements. Remote Sensing of Enviroment. 81: 136-148.

Lehmann, A. 1998: GIS modeling of submerged macrophyte distribution using Generalized Additive Models. Plant Ecology. 139: 113-124.

McFeeters, S.K. 1996: The use of the Normalized Difference Water Index (NDWI) in the delineation of open water features. International Journal of Remote Sensing. 17: $1425-1432$.

Mello, J.A.B. 1980: Usina hidrelétrica de Itumbiara: estudo, formação e enchimento do reservatório e efeitos no meio ambiente. FURNAS: Rio de Janeiro, pp. 33.

Tufford, D.L. \& McKellar, H.N. 1999: Spatial and temporal hydrodynamic and water quality modeling analysis of a large reservoir on the South Carolina (USA) coastal plain. Ecological Modelling. 114: 137-173.

Tundisi, J.G. 1994: Tropical South America: presents and perspectives: In: Margalef, R (ed) Limnology now: a paradigm of planetary problems. Amsterdan: Elsevier Science, pp. 353-424.

Tundisi, J.A., Tundisi, T.M. \& Rocha, O. 2002: Ecossistemas de Águas Interiores. In: Rebouças, A.C.; Braga, B.; Tundisi, J.G. (eds.) Águas Doces no Brasil. São Paulo: escrituras, pp. 153-194.

Valeriano, M.M., Kuplich, T.M., Storino, M., Amaral, B.D., Jr, J.N.M. \& Lima, D.J. 2006: Modeling small watersheds in Brazilian Amazonia with shuttle radar topographic mission-90m data. Computers \& Geosciences. 32: 1169-1181.

WCD. 2000: Dams and development: A framework for decisionmaking. The World Commission on Dams, pp. 412 [http://www.dams.org/]. 
INPE ePrint: sid.inpe.br/mtc-m18@80/2009/09.30.22.11 v1 2009-10-01 